Scientia Militaria vol 44, no 1, 2016, pp 224-237. doi: 10.5787/44-1-1171

\title{
South Africa and the Korean War, the Politics of Involvement
}

\author{
N.M. Van der Waag-Cowling •
}

\begin{abstract}
The Union of South Africa's military involvement in the Korean War was an exercise in political maneuvering as opposed to one of any great military significance. ${ }^{1}$ South Africa's new right wing Nationalist Afrikaner government had, from 1948, embarked on a policy of legislating its racial policies, soon to be known as Apartheid. This new government primarily represented a people who were still deeply scarred by the Anglo Boer War. Many Afrikaners consequently wanted no part in any external conflicts that they viewed as Britain's wars. South Africa's foreign policy therefore became subject to an obvious and decisive shift away from that of the previous government under Jan Smuts, which had been broadly in line with that of Britain and the other Commonwealth dominions. ${ }^{2}$

The Korean War therefore presented the Nationalists with something of a dilemma. They did want to actively promote a stronger relationship with the United States but did not want to become involved in any military ventures with the British Commonwealth. Compounding this problem was the fact that the Nationalist government had identified the growing discontent of South Africa's disenfranchised Black majority as her major security threat. The initial unwillingness of the South African government to commit anything tangible to the United Nations effort in Korea was therefore explicable. Geographically, Korea fell far outside of South Africa's sphere of influence; furthermore this was a conflict which the Union could ill afford. ${ }^{3}$ South Africa had made massive financial sacrifices during the Second World War with contributions to the British war machine that were far beyond her actual reach and was very much still in the grip of post war austerity.

Despite these factors combining to mitigate against South African involvement in Korea and the early isolationist stance of the Nationalist government regarding the Korean crisis, a noticeable and abrupt shift in subsequent policy some two months later bears witness to the theory that the Nationalist government underwent some sort of epiphany with a belated realization as to the potential benefits of military involvement for South Africa. These benefits included the desire of the South African government to be associated with the United States and be included in a formal regional treaty comparable to NATO together with the requirement for the acquisition of certain military hardware. These three aims have been postulated as the principle reason for this rather abrupt foreign policy deviation. This discussion will focus on providing some insight into how the South African government attempted to use the Korean War as a lever in order to attain these foreign policy objectives
\end{abstract}

Keywords: SALO, Cold War, African Defence Organisation, United Nations, South African Air Force

Group for Educational Technology, School for Geo-Spatial Studies and Information Systems, Faculty of Military Science, Stellenbosch University. 


\section{Introduction}

From the inception of the Union in 1910 South Africa had always shown a marked ambiguity towards involvement in foreign conflicts, with English speaking South Africans more inclined to want to take up arms on behalf of the Empire than their Afrikaner compatriots. From 1910 through to 1948, various South African prime ministers found that they could never enjoy significant popular support for foreign military ventures. ${ }^{4}$ The major reason for this was the Nationalist Afrikaner stance on neutrality. Many Afrikaners had no wish to be aligned with Britain, let alone bear the burden of providing military support to the British Commonwealth in far flung, foreign crises not of their making. The entry of South Africa into the Second World War did not occur without a great deal of political wrenching and the government was dogged throughout the conflict by the constant threat of acts of treason and sabotage by right wing groups such as the Ossewa Brandwag within South Africa. Bear in mind then, that when the Korean War erupted, the selfsame right wing Afrikaners had acceded to power in the form of the National Party in $1948 .{ }^{5}$

\section{A new Foreign Policy approach for the Union.}

Domestic issues were cardinal to the new Nationalist government, which had very limited foreign policy objectives when it came to power in 1948. However, the experience of actually governing is a sobering one for any opposition party and it soon became apparent that on the foreign policy front, South Africa was suddenly unsure of her role and place in the New World Order. What is clear, is that the realization had dawned on the government that South Africa would not be able to stand alone in a complex novel environment that had already seen the emergence of the Cold War, independence being granted to former British colonies such as India and Pakistan and the threat of nuclear war. An even more immediate problem was a rapidly rising tide of anti-South African sentiment on the rest of the African continent, where massive changes were beginning to take place as Britain prepared her colonies for independence. The Nationalist government therefore began a tentative search for friends and alliances. However, as it had not yet formulated any specific foreign policy, contradictions in directions were already beginning to emerge.

As the British High Commissioner, Sir Evelyn Baring, reported in September, 1948, the advent of the Nationalist Government in South Africa might have appeared as a setback to Commonwealth Cooperation in defence matters. He observed that its supporters were 'the heirs of a long tradition of antiBritish feeling and activities': 6 during the Second World War they had openly sympathized with Britain's enemies, and they were 'morbidly sensitive' on the subject of the Union's sovereign independence. However, this inherent Anglophobia within Nationalist circles was somewhat offset by the fact that they were with good reason, even more alarmed by the spread of communism.

Despite this pressing reality South Africa had begun to display a startling ambivalence towards the Commonwealth. Barnes postulates that "After Britain, Australia and New Zealand were the most emotionally attached members of the Commonwealth. The conservative Australian and New Zealand Prime Ministers, Robert Menzies and Sidney Holland, were both fervent Anglophiles and looked to Britain to provide leadership". Canada and South Africa on the other hand, displayed a greater degree of independence from Britain. "Canada had its own 'special' relationship with the United States, while its Francophone population, including Prime Minister Louis Saint Laurent, had few emotional ties to the Empire. Meanwhile, the South African government of Daniel Malan, pursuing a policy of Afrikaner nationalism and racial segregation, had little desire to promote the multi-ethnic British Commonwealth." From the 
perspective of Britain and the other Dominions, the Nationalist government appeared to be shunning the Commonwealth. ${ }^{7}$

The South African foreign policy paradigm had undergone a dramatic swing from being pro British in mindset and values to a new stance that favoured closer ties with America. South Africa saw the United States as the beacon of Western cultural values in the New World Order and the natural opponent to communism. By aligning itself with the United States, the Nationalist government hoped to minimize its dependence on Britain as an ally. The Truman administration however, did not feel that Africa fell within its sphere of influence or responsibility and preferred to keep South Africa at arm's length. ${ }^{8}$ Unlike the other Dominions, who constituted key US Allies in North America and the Pacific, South Africa held no strategic significance for the US. However, the Nationalists, whose foreign policy outlook was narrowly conceived and naive, were encouraged by certain developments in the United States. Firstly, the political strength of the so called "Conservative Coalition", the powerful block of Southern Democrats or Dixiecrats whose segregationist values echoed the Nationalists and secondly the rise of Dean Acheson, who framed the Truman Doctrine ${ }^{9}$ to the position of Foreign Secretary may have been viewed as an opportunity to find a sympathetic audience from at least certain quarters in Washington.

\section{A Diplomatic Dilemma: The outbreak of the Korean War}

On 25 June 1950, the massive North Korean force crossed the $38^{\text {th }}$ parallel into South Korea. Within the prevailing Cold War climate, the outbreak of hostilities necessitated a response by Western powers. International reaction to the North Korean invasion was swift and resulted in a UN Security Council Resolution to send a military force to South Korea. ${ }^{10}$ By June 25, 1950, many members of the United Nations had already placed forces at the disposal of the UN Supreme Commander. South Africa, however, despite the fact that she was both a member of the Commonwealth and co-founder of the United Nations, was silent. The British, who were still trying to forge some type of working relationship with the Nationalists recognized immediately that this silence signified South Africa's reticence to send troops. ${ }^{11}$ The Union's Prime Minister Dr D.F. Malan was at that time on holiday in Zululand and apparently did not deem it necessary to interrupt his sojourn with an emergency cabinet meeting. ${ }^{12}$ Malan's new Minister of Defence, Advocate Frans Erasmus traveled instead to Zululand to discuss the situation with him and the result of this discussion was a press statement issued on 1 July 1950 by the Department of External Affairs.

In this statement the Union government identified itself with the Security Council resolution, by condemning the aggression of the North Korean government. The statement went on to say that although the Far East fell outside the sphere of the Union's military responsibility, the Union government would consider, in consultation with the rest of the British Commonwealth, any appeal for assistance received from either "the United Nations or those Countries who associate themselves with the Security Council resolution and are most directly concerned,"13 if future developments made it imperative.

By the middle of July 1950, the government of the United States, which had received responsibility for the UN Command, was vigorously canvassing support in Pretoria. The USA, Britain, Australia and a number of other countries who had become involved, already had forces stationed in South East Asia and post war armies of occupation in Japan. South Africa on the other hand, was ill prepared for such a venture. The Union Defence Force had been cut back to a shadow of its World War Two predecessor and had been the victim of much political meddling by the Nationalists. ${ }^{14}$ It was not battle ready and therefore would have to mobilise, train, equip and dispatch a contingent to a theatre on the far side of the globe. This situation 
was both impractical and unrealistic considering the post war force rationalization and the fact that many senior and experienced officers of Second World War vintage had been purged from service because of their support for the previous government under Smuts. ${ }^{15}$ A further complication was that South Africa's Union Defence Force was almost entirely dependent on Britain for its equipment as well as technical and service knowledge."16

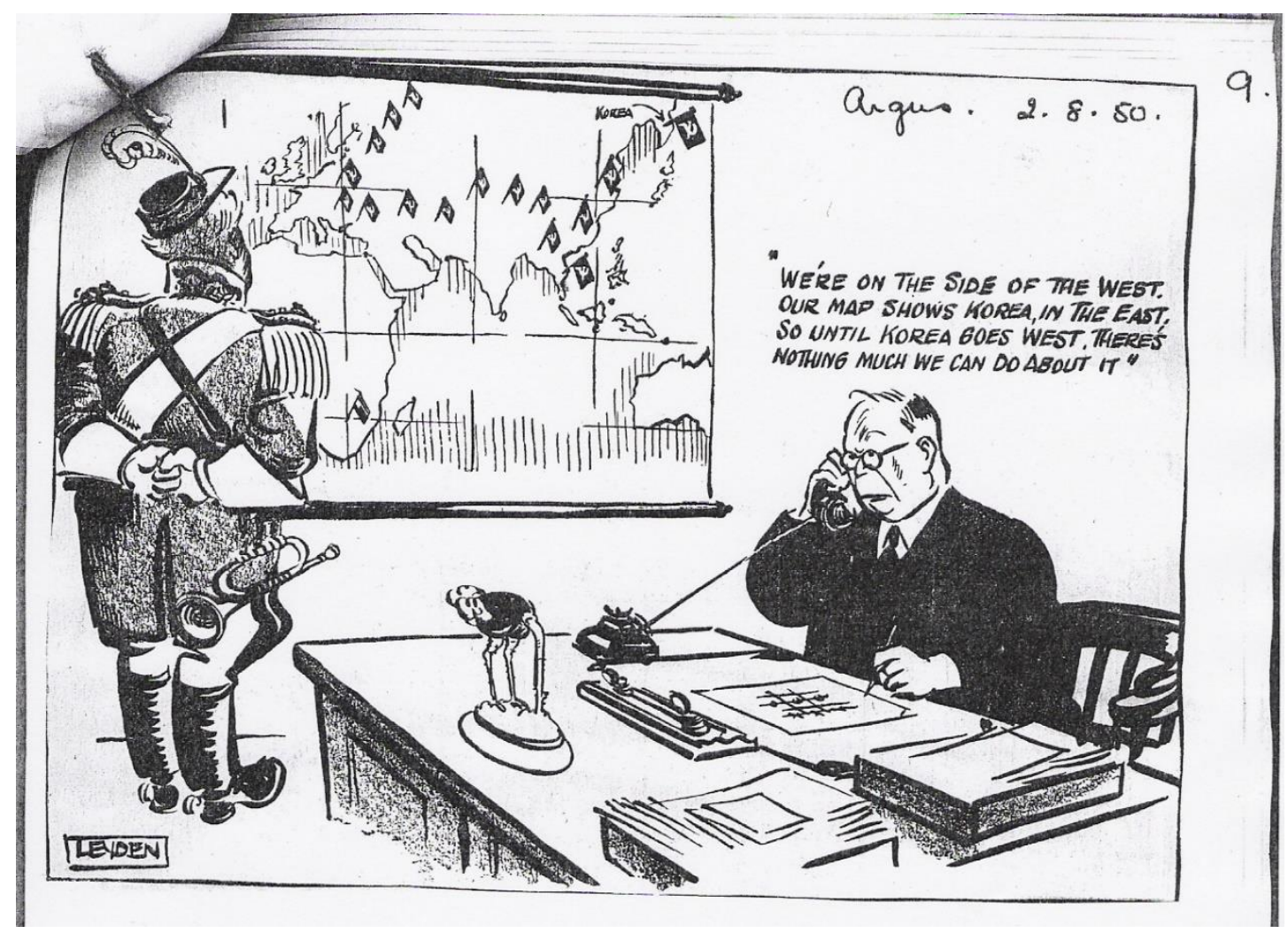

Figure 1: Cartoon illustrating South African approach ${ }^{17}$

The Nationalists were fully aware of this fact and were also facing the added problem of a restlessness from the own backbenchers in parliament who were holding them to the party's longtime clarion call of neutrality. After the government had procrastinated for a long as it could without seeming completely uncooperative, an offer of medical supplies and food provisions was eventually made to the United Nations. ${ }^{18}$ The reaction of the United States to this very unexciting offer was basically that whilst the US was delighted with the stand taken by the South African government it must be stated, quite unequivocally, that direct military assistance was what was required. ${ }^{19}$

\section{South Africa enters the War}

The pressure on South Africa by the UN, her Commonwealth allies and the opposition United Party and English press mounted. It is proposed here that whilst it was common knowledge that the National Party was concerned that the Union would be drawn into further European wars if her strategic plans were 
interwoven with Commonwealth defence schemes; the government was nevertheless, seeking to expand her international relations after 1948. Thus the Nationalists therefore faced a dilemma which was further compounded by the fact that they had also made a separate commitment to support the West in any future wars against Communist powers. ${ }^{20}$

The fear of Communism as a driving ideology behind potential military forces in Africa and the knowledge that she would not cope against an onslaught in Southern Africa without assistance, was forcing the South African government to reassess its traditional view of defence alliances. The previous distaste for military ties with the Commonwealth and the deployment of South African forces beyond the borders of the Union, had to be tempered by reality, and the government actively began to work toward the conclusion of some type of defence treaty. In particular, it was hoped that such a treaty would be concluded with other Western states involved in Africa, or with another Western power possessing an international military capability. ${ }^{21}$ South Africa became intent on seeing the extension of NATO into Africa in the form of the "African Defence Organisation" proposed by Adv F.C. Erasmus, the new Minister of Defence. ${ }^{22}$ Erasmus, was unfortunately totally ill-equipped to make a success of such a difficult task. He was a narrow-minded former teacher from the rural Cape who was spending most of his time in office overseeing the change of the Union Defence Force's uniforms, rank insignias, rank structures and regiments' names. This policy known as the "South Africanisation" of the Union Defence Force was to be his most important work in terms of the legacy it left. Suffice to say that the legacy was never a popular one with English speaking South Africans. ${ }^{23}$

Erasmus and his Defence Staff made at least two visits to Washington, (the first well before the outbreak of the Korean War) in order to promote the idea of an African Defence Organisation. A memorandum within the State Department, recorded the event as follows: "Mr. Erasmus has been in London for discussions with officials of the British Government of plans for the defense of Africa south of the Sahara. He has also explored the possibility of purchasing modern army and air force equipment. Before leaving South Africa a member of his party told our Embassy at Pretoria that if Britain were unable to supply the military equipment in the quantities desired they would seek to obtain the equipment in the United States." ${ }^{24}$ The memo then provides insight into the fact that Erasmus was left disappointed at the US response: "We were frank in our discussions with Mr. Erasmus last year with the result that even though he obtained nothing tangible from his visit he went away with a better understanding and appreciation of the problems with which we are faced in meeting even the most urgent defense requirements of the free world. Furthermore, he returned to South Africa convinced that we were mindful of South Africa's defense problems and of its strategic importance on the African continent. Continued frankness in discussing the strategic position of the United States and its worldwide commitments with Mr. Erasmus will contribute to the maintenance of our present cordial relations with him." ${ }^{25}$ It was against this background of a rather ambivalent yet courteous American approach to South Africa's affairs that the South African government found itself struggling to find a firm niche within the Western power bloc.

Coupled to this search for military and foreign security the South African government was eager to secure an identity as an anti-Communist Western State. ${ }^{26}$ South Africa increasingly found herself in agreement with American and opposed to British foreign policy. When the Indian and Pakistani governments recognized the communist government of Mao Tse-Tung as the de facto government of China, the United Kingdom followed suite and subsequently adopted the same approach. Canada, Australia, New Zealand and South Africa, on the other hand, withheld recognition. This produced a novel situation. Britain found herself in accord with the new members of the Commonwealth, whilst the old Dominions 
increasingly identified themselves with the United States on a number of world issues, including recognition for the Nationalist Chinese.

The United States had clearly attached great value to the stand taken by the supporting countries, in strengthening the hand of the UN. South Africa was eager to join a group of countries carrying the "anticommunist, pro-West" label and share in any possible special treatment passed out by America. This was then clearly an opportunity for the Union to curry favour with the United States that was too good to pass up. South Africa had therefore realized that she had no option but to commit some sort of military force in order to secure her higher foreign policy objectives. The government consequently made a sudden about turn on its proclaimed isolationist stance and announced its decision to send South African forces to Korea on 4 August $1950^{27}$, after having loudly and publicly reaffirmed its neutral policy in the run up to the 1948 election. Ignoring a specific request made to South Africa by the Secretary General of the United Nations of the United Nations for land forces, the government chose to commit a force, known as the "SA Air Force Far East Contingent. This force comprised the "SA Air Force Liaison Headquarters" to be stationed with the Far East Air Forces Headquarters in Tokyo and No 2 Squadron SAAF for deployment in Korea. ${ }^{28}$ Within a few weeks of the government's announcement, a No 2 Squadron contingent of just over 200 men assembled at Waterkloof Air Force Base under the command of former World War Two veteran, Commandant ${ }^{29}$ Servaas van Breda Theron. ${ }^{30}$

An important silver lining to this venture, was the fact that the SAAF was in desperate need of new aircraft, particularly jet aircraft. The government was very astute in quickly creating a scenario that set the stage for the cheap acquisition of jets as a result of military participation. It is worth noting that by the end if the 1940 s only $20 \%$ of the SAAF's aircraft were still serviceable. These serviceable aircraft were also very antiquated being of World War Two vintage. This meant that the Air Force actually had a far greater need for new equipment than any other fighting arm of the South African forces. ${ }^{31}$

The crisis in Korea therefore, provided an initially reluctant government with an opportunity to devise a scheme, which would not only result in the cost-effective acquisition of jets and but also ostensibly expand South Africa's influence abroad. Furthermore, it would send a message both at home and internationally, that South Africa meant business when it came to containing the spread of communism. ${ }^{32}$

\section{The South African Air Force in the Far East}

It soon became apparent that South Africa was intent on placing her squadron under the command of the United States Air Force. This was done for two reasons, firstly to hopefully secure the jet aircraft and secondly to further foster relations between South Africa and US. It had the additional spin-off of ensuring that the government did not have to get into bed with Britain so to speak. 2 Squadron was structured to conform to the establishment tables for a USAF F-51 squadron. It was hoped by the Pretoria government, that with the "Americanisation" of 2 Squadron, the Commonwealth would see the sense of the squadron residing under USAF command and not take offence at the fact that it had not been committed to service with the Commonwealth Air Forces. ${ }^{33}$ South Africa was well aware, that however much she longed for strong ties with the US; this could not be achieved at the expense of isolating her Commonwealth Allies. Consequently, the government had to go to some length to tread a fine line between these two Western power blocks. ${ }^{34}$ The news that the SAAF would be placed under US Command was, however not at all well received in Britain and would later force the South African government to make a token gesture in terms of an Army contingent to serve with the Commonwealth Division. ${ }^{35}$ 
Aside from 2 Squadron and administrative SAAF echelon was also sent to the Far East theatre. The SAAF Liaison Headquarters (SALO HQ) was established with a view to providing support and facilitating communications between South Africa and the Squadron in the Far East. ${ }^{36}$ The HQ was housed in Tokyo, together with the majority of the United Nations Forces (UNF) Staff Divisions. The main function of the Office was in fact to head a wartime diplomatic mission. The SAAF Liaison Officer (SALO) was at the time actually South Africa's chief representative in the Far East and this consequently marked the beginning of diplomatic relations between Japan and South Africa.

The history of the SALO and his staff is one that is littered with pitfalls, setbacks and frustration. The Office was chronically understaffed and underfunded. The SAAF Liaison Officer only held the rank of Colonel whilst most of his peers were at least Brigadier Generals. The failure of the government to address these shortcomings is a clear demonstration of the lack of preparedness and tactical nous on the part of those in power and ultimately bedeviled the SALO's chances for successful interaction in a large and competitive wartime arena.

The SALO was also expected to promote South African industry, tourism and try to sell the new Apartheid government policies in both Japan and Korea. As a result of the limited resources, wide-ranging ignorance about South Africa remained prolific amongst the rank and file other forces serving in the theatre. A case in point was the small SA insignia worn on the lapels of the SAAF tunics. The reaction of almost everyone in the theatre was the assumption that SA stood for either: the Salvation Army, South America, South Australia or Southern Asia. Needless to say this startling revelation as to South Africa's apparent lack of importance in the international order of things must have been a sobering experience for all its personnel in the Far East.

If the SALO's history was one characterized by missed opportunities then the history of 2 Squadron itself, who operated under the legend, "The Flying Cheetahs" was an illustrious one, evidenced by the popularity and overwhelming success of the Squadron. Nevertheless, the early months of operation in the Korean theatre did bear witness to the difficulties experienced by the SAAF personnel in learning to operate within a USAF environment, something that was completely foreign to them. The Squadron's first few months in Korea were peppered with unsavoury incidents which could have seriously undermined everything the South African government was trying to achieve. ${ }^{37}$ It would appear as if squadron members were, at times, guilty of the notion that because the South African contingent in Korea was so small that this made them very special. This could have been avoided if attitudes within the Squadron had been a little more temperate. ${ }^{38}$ Fortunately, once 2 Squadron was ensconced with the $18^{\text {th }}$ USAF Fighter-Bomber Wing, the relationship between the South African and the American personnel improved markedly to the extent that these two fighting units now remember one another with regard and respect.

The long awaited conversion to jet aircraft took place in 1952 when Sabres replaced the SAAF Mustangs. These rather ungraceful but highly effective jets later formed the backbone of the SAAF's attack force until the 1970s when they were replaced by Dassualt Mirages from France. The jet conversion had been a long time coming and two years into the war the South African government became concerned that one of its primary objectives in committing forces to Korea would remain unfulfilled. Erasmus called on the US Ambassador in November, 1951 to underline South Africa's concern and it is clear from the correspondence which followed the meeting between the Ambassador and Washington that the Government was clearly feeling the pressure from its own backbenchers to withdraw forces from Korea should the aim of acquiring jets not materialize. Gallmari wrote "Korea was then touched upon. Erasmus said that because of the severe losses of machines and men in Korea, he had felt compelled during the last session of 
Parliament to state in Parliament that the Union Government would undertake to have its squadron in Korea equipped with jets. He said that it was a big disappointment when he was told by both the British and by us that jets were not now available. He said South Africa, in view of public opinion, was in the position where unless jets were made available the squadron would have to be grounded. From Britain word has come that jets would not be available before 1953. From Ambassador Jooste, however, he had just received word that we would give the problem prompt consideration and that hope was held out, according to Jooste, that perhaps by January some jets could be made available. I asked Erasmus from whom Jooste had received this information. That he said he did not know. The situation, he then said, might, of course, be eased if the cease-fire were soon negotiated. In any event, he said even a few jets by January would ease the Government's position materially. Before we left this subject I reminded Erasmus that we had two squadrons fighting alongside the South African squadron in Korea, and that these squadrons, because of the shortage of jets, were equipped no different from the South African squadron.5"39

The jets were not supplied by early 1952 and as a result the South African ambassador to the United States, G.P. Jooste, notified the State Department that 2 Squadron would be withdrawing from Korea at the end of March 1952. ${ }^{40}$ The US reaction to this announcement was immediate and deeply gratifying for the South African Government. The US affirmed its intention to equip 2 Squadron with Sabres at the soonest possible instance and reiterated the importance of the South African assistance. It was almost a year later, however, before the Sabres were actually delivered. ${ }^{41}$

By the end of the war 2 Squadron had deservedly earned a reputation as an ace fighter unit and gained much in the way of experience, both combat and otherwise. During its service in Korea over eight hundred SAAF personnel served with 2 Squadron. 2 Squadron deservedly earned a revered place in South African military history. It was something of a miscarriage of administrative justice that the South African Army and Medical Corps troops who went on to serve with the Commonwealth Division were never publicly acknowledged by the South African government.

\section{The South African Army and the $1^{\text {st }}$ Commonwealth Division}

Although the formation of a Commonwealth Division had been under consideration at the British War Office and in Australia and New Zealand for some time, ${ }^{42}$ London was not keen to expand the Commonwealth forces in Korea to divisional strength unless significant support was to be forthcoming from the Dominions. With a subsequent increase in troops from Australia and New Zealand and a medical element from India a Commonwealth Division was formed in mid-1951 ${ }^{43}$. There was however, one conspicuous hiatus, South Africa was not represented.

As a consequence the United Kingdom re-opened the question of a South African army contingent with the Union Government in August 1950. In secret negotiations between Evelyn Baring, Britain's High Commissioner to South Africa and Minister Erasmus it was agreed to send a small contingent of Army Officers to Korea. Britain dangled a carrot in front of the South Africans by stressing that the attachment of such a contingent to the Division would not only lighten the burden of the United Kingdom but also enhance South Africa's prestige with the United States and the rest of the United Nations. It appears that this rather transparent psychology worked and South Africa acceded to committing a small force to the Division. The South African government however, did not want this arrangement to be made public at home and eventually the British agreed. ${ }^{44}$ 
When the Cape Times published a report on the agreement, Erasmus denied that there was any truth whatsoever in the matter. Erasmus apparently hoped to avoid political embarrassment due to his party's proclaimed neutral stance. This however, does not make sense as the government had already committed an air force squadron to the conflict. It was therefore, more likely an attempt to cover up any co-operation between the National Party and their traditional foe, the British. So effective was this clouding of secrecy, that even today most people are unaware of the fact that South Africa committed token ground forces and that these were attached to the $1^{\text {st }}$ Commonwealth Division. Once in Korea, this handful of South African Army officers who served in Korea were more or less fully under the command of the Commonwealth as the government went to great pains to distance itself from their existence. Although the SAAF Headquarters was not responsible for the administration of these officers, the Senior Air Liaison Officer did monitor their progress, made their transport arrangements and liaised with the Australian paymasters to make sure that they received their pay as scheduled. The only SALO to visit the land force officers in Korea was Colonel du Toit who visited the 1st Division Headquarters in 1953 after the ceasefire when he informed the South African officers of the Union's withdrawal plans. ${ }^{45}$

After the cessation of hostilities, the government's duplicitous behavior continued and it even went so far as to refuse the land force personnel permission to accept theatre service medals from Britain, although they allowed 2 Squadron personnel to receive medals from the United States. This was a rather shameful act, both for the men who struggled in the arduous and chilling ground campaign and because of the caveat that this has created in the annals of South Africa's military history. It does however, serve as a perfect illustration of the policy dichotomy that the Korean War created for the Nationalists.

\section{The Consequences of South Africa's Involvement}

In hindsight, few would disagree that South Africa had not entered the war in order to further peace in Korea but as a result of self-interest. South Africa needed new military hardware and technology. Of primary interest here was the acquisition of jet aircraft. This, it is postulated, has been incorrectly cited in the past as the principle reason for South Africa's participation in the conflict. It may have been the raison d'etre for sending an air force squadron rather than committing the much needed ground troops but it was not the basis for involvement per se. Once again the question as to why the squadron was placed under command of the USAF and not the Commonwealth Air Forces bears testimony to the fact that this decision was secondary in importance to that of forging stronger ties with the United States. After all, the SAAF contingent would have integrated far more easily into the Commonwealth forces for reasons of organization and equipment.

South Africa's ulterior motives were not lost on the Americans either. The US Secretary of State for Defense voiced his concerns in this regard as early as 1950 when he said that he was of the opinion that South Africa was only making use of this opportunity in order to acquire certain military hardware. ${ }^{46}$ As a result South Africa had to enter two agreements with the United States in terms of participation in Korea. The first concerned South Africa's involvement in the conflict. The second detailed the United States' provision of hardware, supplies and logistical support to the SAAF and was structured in terms of the US Mutual Defence Assistance Act. Under this agreement, aircraft were to be loaned to the SAAF by the United States and South Africa would have to deliver certain strategic raw materials to the US, most notably manganese and uranium. The South African government balked at this last part of the agreement and made some low-key objections but signed the contract nevertheless. ${ }^{47}$ 
South Africa spent $£ 6302417$ on her war effort in Korea. Although this was rather more than South Africa would have liked to spend, due to the onset of the Cold War, the acquisition of modern military hardware was problematic throughout the 1940s and 1950s and Korea provided a window of opportunity that simply had to be exploited. The aircraft acquisition agreements with the United States were in any case, extremely favourable. For example the Mustang aircraft which normally retailed at $\$ 58000$ each were bought by South Africa for a mere $\$ 5447$ each. ${ }^{48}$

The second factor and, probably the more important question which deserves attention is what were, if any, the political gains for South Africa arising from participation in the Korean War? It is the contention of this paper that states seldom become involved in conflicts for ideological reasons alone. War usually has its source in the competition for resources and influence. These reasons are normally intertwined and eventually fuse into an inseparable mass that can be broadly described as being part of the national interest, South Africa bore testimony to this theory. This decision on the part of the Nationalist government to commit a squadron and troops to Korea was based on a number of political factors, which should be mentioned in terms of their priority to the government of the day.

Firstly, South Africa had a desire to establish and entrench a firm bond of friendship and cooperation with the United Sates for reasons that have already been discussed. This was of paramount importance to the Government, which no longer regarded Britain as a world power and for historical reasons, was eager to relegate the Union's relationship with Britain to one of secondary importance.

Whilst these may have been the foreign policy intentions of the South African government, the view from Washington could not have been more dissimilar. Schraeder provides an insightful view on U.S. Africa policy formulation: "In a process that almost inevitably leads to neglect of Africa, Presidents are forced by necessity to select those countries, geographical regions and functional issues which receive priority attention by their Administrations. Indeed, although contacts between the U.S. and Africa have expanded in both quantity and quality during the post- World War 2 period, Presidents from Harry S. Truman to George Bush traditionally have been least interested in, and subsequently have paid least attention to, Africa relative to other regions of the world." 49

Over the following three decades, the limitation of the US-South Africa relationship would be sorely tested. There was to be continuing uncertainty about Washington's attitudes toward South Africa, and indeed Africa as a whole. The Americans had few links with Africa and they did not perceive any communist danger on the Continent either. ${ }^{50}$ In fact, much to the chagrin of Pretoria, the US would sometimes associate South Africa with its critical stance on colonialism in Africa. Later on South Africa became an irritant which embarrassed the US at the General Assembly. ${ }^{51}$ When the US did eventually begin to realize that Marxist-Leninist ideology did enjoy popular support in Africa, it did not come to rely on South Africa for assistance in combating communism. In fact, Washington was quick to comprehend that an alliance with South Africa was far more of a hindrance than a help because the anti-communist groups mistrusted the South Africans almost as much as they did the communists. ${ }^{52}$ Even during the early years of Apartheid, President Truman was being publicly criticized by various African American leaders and sectors of the press for demanding votes for Bulgarians in Communist Eastern Europe but not for Blacks in South Africa. ${ }^{53}$ From a military point of view, the most notable incident was the Operation Savannah debacle, which pressed the then Prime Minister, John Vorster, to comment that, "when it comes to the worst, South Africa stands alone." 54 
In hindsight, South Africa should have spent more energy investing in a stronger relationship with Britain. These two countries not only enjoyed firm historical ties but important trade links and Commonwealth bonds as well. Among Western States, this relationship was destined to remain the most important, although for the Nationalists it was always a complex love-hate affair. Britain proved to be South Africa's most solid Western Ally although relations were cooler and more formal than they had been under Smuts. ${ }^{55}$

The second priority was the National Party's aspiration to be a founder member of (or at least a member of) a Southern counter-part to NATO. Two such groups had already been proposed, the first being SATO (Southern African Treaty Organisation) and the second the African Defence Organisation (ADO). South Africa rightly or wrongly, held that any such organization would be meaningless without the full participation of the United States and the other NATO powers who had interests in Africa. The reasoning behind South Africa's participation in the Korean War was consequently that South Africa must make a solid gesture towards the strategic interests of the West in the Far East in order to illicit reciprocal responses from the West towards South Africa's strategic interests in Africa. These proposed organizations were stillborn because in the first place, the Nationalist government had hopelessly overestimated the importance of Africa to the West ${ }^{56}$ and secondly due to South Africa's growing status as a pariah state, she would find herself fighting her wars alone. ${ }^{57} 58$

A final consideration was that South Africa felt obliged to demonstrate her commitment to the United Nations. Criticism of Apartheid was becoming widespread and vocal both at the UN and also in a general global context. The National Party realized that by supporting the West in the Far East, it would be more difficult for Western states to openly criticize these policies whilst accepting South Africa's military assistance. Of equal significance here was the stance of the National Party on Communism. "The NP presented apartheid and anti-communism as its twin formulas for combating the dual dangers of Black Nationalism and communism." 59 Thus, the participation of the UDF in Korea was to a certain extent an inevitable follow through of national policy and a handy instrument for bringing the message home to those who doubted the threat of communism. For the NP's spin doctors, Korea provided a convenient showcase which bore testimony to the spread of this rampant phenomenon and that the NP would stop at nothing to achieve the eradication of the ideology, even if this meant traveling to the other side of the globe to do it.

\section{Conclusion}

The National Party proved to be short sighted in its belief that by sending a token force to Korea, South Africa could stem the rising tide of international criticism against her racial policies. It would appear as if the National Party was convinced that a strong stand against communism would somehow cancel international criticism against Apartheid. Indeed, the government had identified communism as its main threat both domestically and internationally. 'Because communists challenged white rule across Africa there was a temptation in Pretoria to believe that all who challenged white rule were therefore communists. ${ }^{60}$ Consequently the Nationalists thought they could still sell Apartheid in the West under this guise if they demonstrated a commitment to the West. This however, was not to be, most western governments realized that the two issues were not necessarily intertwined and they increasingly held South Africa at arm's length. The same can be said of South Africa's relations with the United Nations. This association was not assisted by the Korean experience in the long term, as the issues of the South West Africa mandate and Apartheid were to prove decisive factors in determining the development of UN-South 
African relations. The National Party's determination to legislate it racial polices was a major factor in contributing to South Africa's weakened position after the Second World War. ${ }^{61}$ Korea could not and did not prevent South Africa's slide from paragon to international polecat.

1 Unless otherwise stated, all archival references refer to material in custody of the Military Archives Depot (Documentation Service Directorate of the South African National Defence Force, Pretoria.

2 D. Worrall, South Africa, Government and Politics (Van Schaik, Pretoria, 1980), p 288.

3 Archives of the Chief of Staff Intelligence (hereinafter AMI) Group 3, Box 1011, file GS/37 vol II Intelligence Policy: Chief of the General Staff - Union Ambassador at The Hague, 12 Nov 1951.

4 See, for example, I.J. van der Waag, 'South Africa and the War in Asia Minor, 1920-1923', Militaria 24(1) 1994, pp 9-19.

$5 \quad$ I.J. Van der Waag, A Military History of Modern South Africa, (Jonathan Ball, Cape Town, 2015) p 174.

$6 \quad$ R. Ovendale, 'The South African Policy of the British Labour Government, 1947-1951.' International Affairs (Royal Institute of International Affairs) Vol. 59, No. 1 (Winter, 1982-1983) p 44.

7 R. Barnes, 'Branding an Aggressor: The Commonwealth, the United Nations and Chinese Intervention in the Korean War, November 1950-January 1951'. The Journal of Strategic Studies, Vol. 33, No. 2, April 2010, p.234.

8 J. Barber and J. Barratt, South Africa's Foreign Policy, 1945-1970. (Cambridge University Press, United Kingdom, 1990), p49.

9 The Truman Doctrine the principle that the US should give support to countries or peoples threatened by Soviet forces or Communist insurrection. With the Truman Doctrine, President Harry S. Truman established that the United States would provide political, military and economic assistance to all democratic nations under threat from external or internal authoritarian forces. (https://history.state.gov/milestones/19451952/truman-doctrine)

I.J. Van der Waag, A Military History of Modern South Africa, (Jonathan Ball, Cape Town, 2015), p 228. L. Jooste, 'F.C. Erasmus as Minister van Verdediging 1948-1959' (Unpub MA Dissertation UNISA) p 179. L. Jooste, 'F.C. Erasmus as Minister van Verdediging 1948-1959' (Unpub MA Dissertation UNISA) p 179.

Archives of the Military Advisor to the High Commissioner for the Union of South Africa, London (hereinafter MA), Box 422, file Korea: Secretary for External Affairs, Pretoria - High Commissioner to the Union, Canberra, 1 Jul 1950.

PRO: PREM 11/274 Ian Jacob to Prime Minister, 1 Jul 1952.

Although statistics are not readily available, the UDF was purged of most of its general (and many field) officers after 1948. Certainly those with an "English" orientation were either fired or retrenched or worked out in some way.

R. Ovendale, 'The South African Policy of the British Labour Government, 1947-1951.' International Affairs (Royal Institute of International Affairs) Vol. 59, No. 1 (Winter, 1982-1983) p 44.

United Party Archives, Division of Research and Information, Newspaper clippings, The Argus, 2 Aug 1950. L. Jooste, 'F.C. Erasmus as Minister van Verdediging 1948-1959' (Unpub MA Dissertation UNISA), pp 180. D.M. Moore, The Role of the South African Air Force in the Korean War, 1950-1953 (Unpub D Phil these, UNISA, 1982), p 90; and the MA, Box 422, file MA/TS/1014 Korea: Enc 13 Acting Military Advisor - Chief of the General Staff, 31 Ju 1950.

D.J. Geldenhuys, Isolated States: A Comparative Analysis, Jonathan Ball, Cape Town, 1990, p 121.

R. Ovendale, 'The South African Policy of the British Labour Government, 1947-1951.' International Affairs (Royal Institute of International Affairs) Vol. 59, No. 1 (Winter, 1982-1983) pp 45, 50.

Archives of the Minister of Defence, Erasmus and Fouche collection (hereinafter MVEF), Box 1, file G. 171 Discussions between the UK USA and Union Governments: enc 2 "Regional Defence in Africa", 3 Mar 1949.

N.M. Cowling, A History of Military Nomenclature in South Africa. Militaria, Vol 23, No 3 (1993).

FOREIGN RELATIONS OF THE UNITED STATES, 1950, THE NEAR EAST, SOUTH ASIA, AND AFRICA, VOLUME V, Memorandum by the Assistant Secretary of State for European Affairs (Perkins) to the Secretary of State. "Visit of the Honorable F. C. Erasmus, Minister of Defense of the Union of South Africa." Washington October 2, 1950. 
FOREIGN RELATIONS OF THE UNITED STATES, 1950, THE NEAR EAST, SOUTH ASIA, AND AFRICA, VOLUME V, Memorandum by the Assistant Secretary of State for European Affairs (Perkins) to the Secretary of State. "Visit of the Honorable F. C. Erasmus, Minister of Defense of the Union of South Africa." Washington October 2, 1950.

J. Barber and J. Barratt, South Africa's Foreign Policy, 1945-1970. (Cambridge University Press, United Kingdom, 1990), p 81.

MA. Box 422, file MA/TS/1014 Korea: Enc. 6 MOD London - UK Service Liaison Staffs in Ottawa, Wellington and Pretoria, 28 June 1950. and DC (5), Box 57, File DC 17850/362/1 Korean Campaign, Military and non military assistance: Enc. 8a Secretary for External Affairs, Pretoria - High Commissioners in London, Ottawa and Canberra, and the Minister of External Affairs, Wellington, 4 Aug 1950.

Archives of the Adjutant General (hereinafter AG) 3, Box 228, file AG 93) 1906/14/voll, Organisation Korea Campaign Military Assistance to UNO: Enc. 25 (a) circular AG (3) 1906/14 dated 2 Sep 1950.

Lieutenant Colonel.

I.J. Van der Waag, A Military History of Modern South Africa, (Jonathan Ball, Cape Town, 2015) p. 229.

L. Jooste, 'F.C. Erasmus as Minister van Verdediging 1948-1959' (Unpub MA Dissertation UNISA), pp 134 et seq.

MA. Box 422, file MA/TS/1014 Korea: Enc. 6 MOD London - UK Service Liaison Staffs in Ottawa, Wellington and Pretoria, 28 June 1950. and DC (5), Box 57, File DC 17850/362/1 Korean Campaign, Military and non military assistance: Enc. 8a Secretary for External Affairs, Pretoria - High Commissioners in London, Ottawa and Canberra, and the Minister of External Affairs, Wellington, 4 Aug 1950.

War Diaries and Missions Korea (hereinafter WDM), Box 9 SAAF Liaison Headquarters, 20-22 Sep 1950. WDM, Box 9, SAAF Liaison Headquarters, 23-24 September 1950.

I.J. van der Waag, A Military History of Modern South Africa, (Jonathan Ball, Cape Town, 2015). pp. 229, 232.

Archives of the Senior Air Liaison Officer (Hereinafter SALO), Box 7, file SALO/S/818/1ORG Organisation SAAF Korea Contingent: Enc 13 Organisation and Administrative Instruction Part 1 No 26 DGAF/0/818/100/13/ORG dated 7 Sep 1950.

D. Moore and P. Bagshawe, South Africa's Flying Cheetah's in Korea. (Ashanti, Johannesburg, 1991), p 6. WDM, Box 9, SAAF Liaison Headquarters, 20 March 1953.

The (United States) Ambassador in the Union of South Africa (Gallmari) to the US Department of State. Pretoria, November 5, 1951. FOREIGN RELATIONS OF THE UNITED STATES, 1951, THE NEAR EAST AND AFRICA, VOLUME V. Office of the Historian, Department of State.

SALO, Box 1, file SALO/TS/23/1 Air Policy Union, Employment of 2 SAAF Squadron. GHQ UDF, 21 Feb 1952.

SALO, Box 1, file SALO/TS/23/1 Air Policy Union, Employment of 2 SAAF Squadron. DGAF-SAAF Liaison HQ, 27 Mar 1952.

J. Grey, The Commonwealth armies and Korean War; An alliance study (Manchester University Press, Manchester and New York, 1988), p 89.

D. Chandler and I. Beckett; The Oxford Illustrated History of the British Army (Oxford University Press, Oxford and New York, 1994), p 338.

AG(3), Box 228, file AG(3) 1906/14 Voll Organisation Korea Campaign, Military Assistance to UNO: Baring-Erasmus, 12 Aug 1950; and DC (5), Box 57, file DC 17850/362/1 Korean Campaign, military and non-military assistance: Secretary for External Affairs, Pretoria - High Commissioner, Canberra and Minister of External Affairs, Wellington, 21 Jul 1950.

WDM, Box 9, SAAF Liaison Headquarters, 6 March-3 April 1952; and Tape recordings by Lieutenant General J. Dutton.

L. Jooste, 'F.C. Erasmus as Minister van Verdediging 1948-1959', p 181.

MVEF, Box 150, Annual Report of the Department of Defence for Year ended Mar 1952.

L. Jooste, 'F.C. Erasmus as Minister van Verdediging 1948-1959', p 142.

P.J. Schraeder, 'Speaking with Many Voices: Continuity and Change in U.S. Africa Policies.' The Journal of Modern African Studies, 29, 3 (I99I), pp. 373-4I2, p375.

P.J. Schraeder, 'Speaking with Many Voices: Continuity and Change in U.S. Africa Policies.' The Journal of Modern African Studies, 29, 3 (I99I), p. 387.

J. Barber and J. Barratt, South Africa's Foreign Policy, 1945-1970. (Cambridge University Press, United Kingdom, 1990), p 48.

W. Isaacson, Kissinger - a Biography,(Faber and Faber, London and Boston, 1992), p 687. 
T. Patterson, Meeting the Communist Threat (Oxford University Press, New York and Oxford, 1988) p 98. D.J. Geldenhuys, Isolated States: A Comparative Analysis, (Jonathan Ball, Cape Town, 1990), p 467.

PRO: PREM 11/274 Ian Jacob to Prime Minister, 1 Jul 1952. See also J. Barber and J. Barratt, South Africa's Foreign Policy, 1945-1970. (Cambridge University Press, United Kingdom, 1990), p. 47.

L. Jooste, 'F.C. Erasmus as Minister van Verdediging 1948-1959', p 193

L. Jooste, 'F.C. Erasmus as Minister van Verdediging 1948-1959', p 196

P.J. Schraeder, 'Speaking with Many Voices: Continuity and Change in U.S. Africa Policies.' The Journal of Modern African Studies, 29, 3 (I99I), pp. 391.

D.J. Geldenhuys, Isolated States: A Comparative Analysis, (Jonathan Ball, Cape Town, 1990), p 456.

J. Barber and J. Barratt, South Africa's Foreign Policy, 1945-1970. (Cambridge University Press, United Kingdom, 1990), p 45.

D. Worrall, South Africa, Government and Politics. (Van Schaik, Pretoria, 1980), p 290. 